Available online at : http://journal.unj.ac.id/unj/index.php/gjik

Gladi : Jurnal Ilmu Keolahragaan 12 (04) 2021, 216-222

Permalink/DOI: https://doi.org/10.21009/GJIK.124.01

\title{
ANALYSIS OF PHYSICAL EDUCATION INSTRUCTION USING ASYNCHRONOUS METHOD ON A DISTANCE LEARNING SYSTEM
}

\author{
Leli Rahman', Taufik Rihatno ${ }^{2}$, Fatah Nurdin² \\ ${ }^{1}$ SMA Negeri 1 Cisarua Bogor, Jl. Adhijaksa RT.02/RW.02 Desa Leuwimalang, Kec, Cisarua, Kabupaten Bogor \\ ${ }^{2,3}$ Pendidikan Jasmani, Pascasarjana Universitas Negeri Jakarta, \\ Komplek Universitas Negeri Jakarta Gedung M. Hatta Jl. Rawamangun Muka, Jakarta Timur, Indonesia 13220
}

Corresponding Email: lelirahman39@gmail.com

\begin{abstract}
This study aims to find out how the level of learning activity using the method asynchronous in distance learning. The research method uses descriptive analysis method. The research population was students of SMAN 1 Cisarua in the 2020/2021 academic year with a total sample of 90 people, while the instrument used in this study was a learning activity questionnaire. The data analysis technique used relative frequency distribution and trend test. The results showed that the "Very Good" category obtained a percentage of 8\%, in the "Good" category a percentage of 22\% was obtained, in the "Enough" category a percentage was obtained $41 \%$, in the "Less" category the percentage was 23\%, while in the "Very Poor" category, a percentage of $6 \%$ is obtained. From the results of this study, it can be concluded that the level of physical education learning activities through the use of asynchronous media is in the sufficient category, although in terms of implementation it is still not optimal and there are several shortcomings, but the most important thing is that learning activities must continue to be carried out even in limited conditions
\end{abstract}

Keywords: Analysis; Physical education ; Learning methods;asynchronous; Distance Learning.

\section{INTRODUCTION}

At the beginning of 2021, conditions have not experienced significant changes related to the outbreak of the covid-19 virus which still has an impact on human survival, including in the field of education. Many activity agendas were canceled, besides that work and study were also carried out from home so that the term Work from home or learning from home became popular among the public. Covid-19 has also had a serious impact on the education sector, both in Indonesia and globally (Purwanto et al., 2020)

Learning activities in schools are still not carried out normally, so that it will have an impact on the psychological condition and physical condition of students. With conditions that hinder human activity, it does not mean that physical activity also stops, in maintaining health it is necessary to maintain and improve the quality of physical fitness, therefore a special strategy is needed in learning physical education with a distance learning system (PJJ) so that students can learn safely and continue to do physical activity to meet physical needs during the pandemic. Regular physical activity is considered as one of the important components of a healthy lifestyle(Setiawan et al., 2021), so that if students have a good level 
of fitness and health, they will be able to learn and do activities well.

Of the various materials studied in physical education lessons, of course, the fulfillment of physical needs should be the main focus in the selection of materials, in line with Government provisions in this case the Ministry of Education and Culture which emphasizes the meaning of learning and provides essential material in physical education learning. One of the materials that can support students in realizing active living activities and help in maintaining fitness is rhythmic gymnastics learning materials. Rhythmic gymnastics has many benefits for the body, including improving physical shape, improving heart health, mental health and maintaining physical fitness(Abdullah et al., 2020) By studying rhythmic gymnastics, it is expected that students can understand and be able to carry out motion activities to meet their physical needs.

With the distance learning system (PJJ) the provision of material and the implementation of movement activities will more or less experience difficulties because it is not carried out face-to-face or directly, so it requires the role of learning media as an intermediary in delivering material from educators to students. Media has the function of paving the way to the achievement of teaching goals. This is based on the belief that the teaching and learning process with the help of the media enhances the learning activities of students in a fairly long period of time(Yusmawati et al., 2020).

In this era of technological development, there are many media that can be used as learning aids. There are so many learning media technologies in the form of platforms that are used in every educational institution, at the school and university level to streamline the learning process carried out. Such as Google Classroom, E-learning, YouTube, WhatsApp, Edmodo, Zoom, Google meet and other platforms that can support learning facilities from home (Habibah et al., 2020).

With the use of distance learning systems, there are several learning methods that are considered suitable for achieving learning objectives, Synchronous and Asynchronous learning methods are the most widely used methods, to interact in the learning environment. (Narayana, 2016)This is based on the advantages obtained from this method, namely that it lies in a learning system that does not always require educators and students to meet face-to-face at the same place and time. The difference between synchronous and asynchronous learning lies in the learning time and interactions carried out where students and instructors exchange information and interact simultaneously in an online learning community using a predetermined time using learning technologies including internet conference, satellite, video teleconferencing and chat. as 
well as media zoom, google meet and other media(Narayana, 2016), while asynchronous is more flexible not bound by time which can be accessed at any time such as Google class room media, Edmodo, LMS and other media.

Various studies have discussed learning during the pandemic with a distance learning system known as BDR (Learning from Home). As well as research that has been carried out (Rochman et al., 2020) which states that educational learning has been going well, but has not been implemented optimally because there are still various obstacles such as lack of understanding of information technology during the implementation of learning, and lack of preparation. In addition to obstacles related to understanding information technology, there are still other obstacles such as the motivation of students in participating in PJOK learning as expressed by(Komarudin \& Subekti, 2021)that the level of satisfaction of junior high school students is low. From the two studies, it can be concluded that online learning in the distance learning period is still not optimal, so it needs to be studied further, especially in the learning process carried out whether the process carried out is optimal or not.

When viewed in terms of the learning process carried out there are steps taken by the teacher in delivering the material and using various techniques and media that are considered capable of conveying material from the teacher as a facilitator to students.
When viewed from the flexibility of learning time and task execution, the asynchronous method is very suitable for use in rhythmic gymnastics learning because it can provide flexibility for students to be able to develop their movement activities and students can choose the time anytime and anywhere, and must remain under the supervision of the teacher. as a facilitator. However, each method and learning media of course have advantages and disadvantages when viewed in terms of application in learning,

From the explanation above, the researcher wants to know how the level of learning activity using asynchronous learning in distance learning is.

\section{METHOD}

This research method uses descriptive analysis method, by describing the research results. This is intended to analyze the activity level of the physical education learning process on the rhythmic gymnastics material carried out at SMAN 1 Cisarua. The approach used is descriptive qualitative research.

The research population in writing is students of SMAN 1 Cisarua which consists of 934 students, while to determine the number of samples using the formula proposed by Slovin (Riyanto \& Hatmawan, 2020) with a confidence level of $90 \%$ with a value of $\mathrm{e}=10 \%$, as for the calculation using the following formula:

$$
\text { Rumus : } \mathrm{n}=\frac{N}{1+\mathrm{Ne}^{2}}
$$


Based on the calculation of the formula, the number of samples obtained is 90 samples. To take the sample using a systematic sampling technique in multiples of 10 .

The object studied by the author is the analysis of the learning process of rhythmic gymnastics material in the distance learning period, while the instrument used in this research is to use a learning activity questionnaire.

The instrument grid is made based on the steps of the learning process and learning activities carried out by modifying the grid compiled by (Ulfa Soleha et al., 2021)

Table 1. Learning Activity Instrument Grid

\begin{tabular}{|c|c|c|c|}
\hline Aspect & Indicator & Items & Amount \\
\hline Learning & Apperception activities & $1,2,3,4,5$ & 5 \\
\hline \multirow[t]{10}{*}{ Activities } & $\begin{array}{l}\text { Submission of learning } \\
\text { objectives }\end{array}$ & 6.7 & 2 \\
\hline & motivation to learn & $\begin{array}{l}8,9,10,11 \\
12\end{array}$ & 5 \\
\hline & learning difficulty level & $13,14,15,16$ & 4 \\
\hline & $\begin{array}{l}\text { Providing learning } \\
\text { stimulus }\end{array}$ & 17.18 & 2 \\
\hline & Submission of materials & $\begin{array}{l}19,20, \\
21,22,23\end{array}$ & 5 \\
\hline & Retention of material & $24,25,26$ & 3 \\
\hline & $\begin{array}{l}\text { Active involvement of } \\
\text { students in the learning } \\
\text { process }\end{array}$ & $27,28,29,30$ & 4 \\
\hline & $\begin{array}{l}\text { Virtual teacher and } \\
\text { student communication }\end{array}$ & 31.32 & 2 \\
\hline & $\begin{array}{l}\text { obstacles found during } \\
\text { learning }\end{array}$ & 33.34 & 2 \\
\hline & reflection activities & 35 & 1 \\
\hline Product/ & Understanding of the & 36 & 1 \\
\hline \multirow[t]{4}{*}{ Result } & $\begin{array}{l}\text { material obtained from } \\
\text { learning activities }\end{array}$ & & \\
\hline & $\begin{array}{l}\text { Habituation of physical } \\
\text { activity carried out }\end{array}$ & 37 & 1 \\
\hline & $\begin{array}{l}\text { Ability gained from } \\
\text { learning }\end{array}$ & $38,39,40,41$ & 4 \\
\hline & Amount & & 41 \\
\hline
\end{tabular}

The learning activity questionnaire was tested on 30 students and the results obtained from 55 questions contained 41 valid questions with a reliability coefficient of 0.743 .
Data analysis technique using Microsoft excel from calculation of relative frequency distribution and trend test (Ginanjar, 2021).

\section{RESULTS AND DISCUSSION}

The results of the analysis and processing obtained data that there were 7 samples with very good categories who scored $>111$ with a total percentage of $8 \%$. In the good category there are 20 samples who get a score between 101-111 with a total percentage of $22 \%$. In the sufficient category there are 37 samples who get a score between 92-100 with a total percentage of $41 \%$. In the less category there are 21 samples who get a score of $82-91$ with a total percentage of $23 \%$. While in the very poor category there are 5 samples who get a score of $<82$ with a total percentage of $6 \%$. The results of the analysis can be seen in Figure 1 and for the trend test of the research variable data, it can be seen in Table 2 and

Figure 2. Overall, the data obtained can be categorized as sufficient because the overall average score is 96.57 which is in the sufficient category.

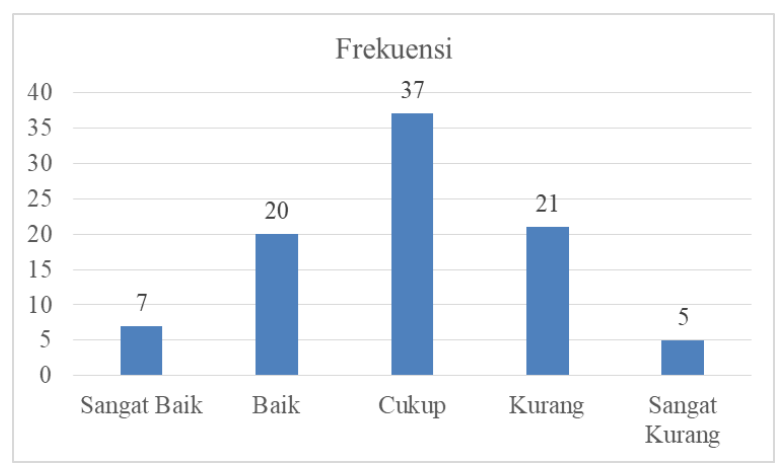

Figure 1. Graph of the acquisition of the frequency of learning activity levels 
Table 2. Test Results Tendency of learning activity level.

\begin{tabular}{cccc}
\hline interval & Category & Frequency & $\begin{array}{c}\text { Percentag } \\
\mathrm{e}\end{array}$ \\
\hline$>111$ & Very good & 7 & $8 \%$ \\
$110-101$ & Well & 20 & $22 \%$ \\
$100-92$ & Enough & 37 & $41 \%$ \\
$91-82$ & Not enough & 21 & $23 \%$ \\
\hline
\end{tabular}

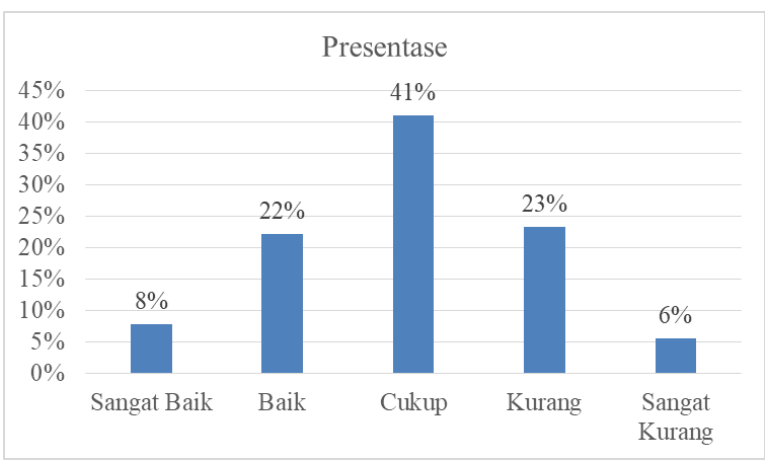

Figure 2. Graph of acquisition of the percentage level of learning activity.

Based on the processing results listed in table 2, it shows that learning activities using the asynchronous method are in the sufficient category because the highest percentage of the 90 samples received a frequency of 37 samples in the sufficient category.

From the results described above, it is actually sufficient to describe how the physical education learning process using asynchronous application-based media is not in very good criteria due to several obstacles found during learning. The obstacles found during learning include: a) Students lack commitment to learning, b) Students are less motivated by the stimulus provided by the teacher, c) Limited distance so that teachers are less able to supervise daily activities during learning d) lack of motivation and supervision provided by parents during learning.

But in addition to the shortcomings and obstacles obtained, there are also advantages of learning activities using asynchronous application media including: a) students are creative through the collection of motion task videos given by the teacher, thus encouraging students to do physical activities and get used to using technology media, b) students have flexible time in doing assignments so that students are given the opportunity to be creative with the timeframe that has been given by the teacher.

From the findings obtained, it can be said that the use of asynchronous media in physical education learning at the high school level, especially at SMAN 1 Cisarua, is quite good although it is still not optimal in terms of implementation and the results obtained are due to limited space and time.

According to (Hudah et al., 2020) based on the results of his research stated that several applications can be used for online learning, such as the use of WhatsApp media, Facebook, telegram, google classroom, and google forms, although learning with these media is considered by many people to be less effective, what must be considered is the safety and safety of students being the focus The main thing is without having to leave his obligations as students in carrying out learning activities, so that the rights of students in obtaining education can be 
fulfilled even though students are in their respective homes.

This research is superior to previous research (Septian Raibowo \& Yahya Eko Nopiyanto, 2020) that from the results of his research, the highest percentage was obtained in the low category with a percentage gain of $46 \%$ and the results stated that the PJOK teaching and learning process during the covid-19 pandemic at the high school level in Bengkulu City was in the "low" category. Then when viewed in terms of categories in carrying out distance learning activities, it is in line with the results of the study(Ulfa Soleha et al., 2021) The similarities can be seen in the categories achieved which state that the results of online learning in the subject of media and physical education learning technology for semester 3 students of FKIP Sriwijaya University in the category are quite effective, although the research was carried out at different levels but in essence physical education learning activities in the learning system remotely implemented fairly well or quite effectively.

\section{CONCLUSION}

This study concludes that the level of physical education learning activity through the use of asynchronous media is in the sufficient category. Physical education learning at the high school level with a distance learning system can be carried out with the use of technology, such as the use of learning media and methods that are in accordance with current conditions as a tool for teachers and students in achieving learning goals, although it is not optimal but learning with the use of media is at least a solution in dealing with the ongoing pandemic situation so as to minimize the transmission of epidemics that can harm students.

\section{BIBLIOGRAPHY}

Abdullah, K., Sujarwo, \& Lubis, J. (2020). Model Pembelajaran Senam Irama Berbasis Media Pembelajaran Pada Siswa Smp. Jurnal Pendidikan Jasmani Dan Adaptif, 02(3), 61-68. https://doi.org/10.21009/jpja.v3i02.1627 1

Ginanjar, A. (2021). Statistika Terapan dalam Pendidikan Jasmani \& Olahraga (1st ed.). Deepublish (CV. Budi Utama).

Habibah, R., Salsabila, U. H., Lestari, W. M., Andaresta, O., \& Yulianingsih, D. (2020). Pemanfaatan Teknologi Media Pembelajaran di Masa Pandemi Covid19. Trapsila: Jurnal Pendidikan Dasar, 2(02), https://doi.org/10.30742/tpd.v2i2.1070

Hudah, M., Ari Widiyatmoko, F., Dwi Pradipta, G., \& Maliki, O. (2020). Analisis Pembelajaran Pendidikan Jasmani Di Masa Pandemi Covid-19 Di Tinjau Dari Penggunaan Media Aplikasi Pembelajaran Dan Usia Guru. Jurnal Porkes, 3(2), 93-102. https://doi.org/10.29408/porkes.v3i2.29 04

Komarudin, K., \& Subekti, B. H. (2021). Tingkat Kepuasan Peserta Didik Terhadap Pembelajaran Pjok Daring. Jambura Health and Sport Journal, 3(1), 16-23.

https://doi.org/10.37311/jhsj.v3i1.9847 
Narayana, I. W. G. (2016). Analisis terhadap hasil penggunaan metode pembelajaran synchronous dan asynchronous. Semnasteknomedia Online, 4(1), 139144.

https://ojs.amikom.ac.id/index.php/semn asteknomedia/article/view/1255

Purwanto, A., Pramono, R., Asbari, M., Santoso, P. B., Wijayanti, L. M., Choi, C. H., \& Putri, R. S. (2020). Studi Eksploratif Dampak Pandemi COVID19 Terhadap Proses Pembelajaran Online di Sekolah Dasar. EduPsyCouns: Journal of Education, Psychology and Counseling, 2(1), 1-12. https://ummaspul.ejournal.id/Edupsycouns/article/view/397 Riyanto, S., \& Hatmawan, A. A. (2020). Metode Riset Penelitian Kuantitatif Penelitian Di Bidang Manajemen, Teknik, Pendidikan Dan Eksperimen. Metode Riset Penelitian Kuantitatif Penelitian Di Bidang Manajemen, Teknik, Pendidikan Dan Eksperimen, 1373.

Septian Raibowo, \& Yahya Eko Nopiyanto. (2020). Proses Belajar Mengajar Pjok Di Masa Pandemi Covid-19. STAND: Journal Sports Teaching and Development, $\quad 1(2), \quad 112-119$. https://doi.org/10.36456/jstand.v1i2.2774

Setiawan, H., Munawwarah, M., Wibowo, E., \& Covid-, W. H. O. (2021). Hubungan Aktivitas Fisik dengan Kebugaran dan Tingkat Stres pada Karyawan Back Office Rumah Sakit Omni Alam Sutera dimasa Pandemi Covid-19. 3(21), 1-10. https://doi.org/https://doi.org/10.22219/ physiohs.v3i1.16935

Ulfa Soleha, U., Hartati, \& Aryanti, S. (2021). ANALISIS PEMBELAJARAN DARING PADA MATA KULIAH MEDIA DAN TEKNOLOGI PEMBELAJARAN PENJASKES
MAHASISWA FKIP UNIVERSITAS SRIWIJAYA. Jurnal Pendidikan Olahraga, 4(1), 9-16. https://doi.org/http://dx.doi.org/10.3160 2/rjpo.v4i1.4997

Yusmawati, Rihatno, T., \& Rismawanti. (2020). Meningkatkan Hasil Belajar Gerak Dasar Melempar dengan Media Audio Visual Pada Siswa Klas III SDN 03 Jelambar Baru Jakarta Barat. Jurnal Segar, 8, 80-89. http://journal.unj.ac.id/unj/index.php/se gar/article/view/15429 